COMITÉ INTERNACIONAL

EN GINEBRA

\title{
Participaciones en los Convenios de Ginebra
}

En carta del 27 de junio de 1975, dirigida al Consejo Federal Suizo y recibida por el mismo el 11 de julio de 1975, el ministro de Asuntos Exteriores de la Commonwealth de Bahamas declara que aquel Estado se considera obligado por los cuatro Convenios de Ginebra del 12 de agosto de 1949.

Con esa participación y la adhesión de la República de GuineaBissau, que el presidente de este último Estado había anteriormente comunicado al Consejo Federal Suizo, el número de Estados Partes en dichos Convenios se eleva ya a 139 . 